Jurnal Riset Biologi dan Aplikasinya

\title{
Distribution Patterns of Exotic Plant Chromolaena odorata, in Rehabilitation Zone at Donglo Block, Resort of Wonoasri, Meru Betiri National Park
}

\author{
Dwi Wardatul Rizkiah, Arif Mohammad Siddiq, Hari Sulistiyowati * \\ Biology Department, Faculty of Mathematics and Natural Sciences, Universitas Negeri Jember \\ Jln. Kalimantan 37, Jember, East Java 6812 1, Indonesia \\ * Corresponding Author: \\ e-mail: sulistiyowati.fmipa@unej.ac.id
}

\section{Article History \\ Received : 7 February 2021 \\ Revised : 7 March 2021 \\ Approved : 22 March 2021 \\ Published : 31 March 2021}

\section{Keywords}

Chromolaena odorata; distribution pattern; exotic plants; Meru Betiri National Park

\begin{abstract}
Exotic plants are plants that are introduced intentionally or unintentionally from their original habitat to a new habitat. One of the exotic plants that is potentially invasive is Chromolaena odorata. These plants are found a lot especially in the rehabilitation zone at Donglo Block Resort of Wonoasri, Meru Betiri National Park (MBNP). An initial effort to determine whether this exotic plant was potentially invasive was to use the distribution pattern of a plant population. This study aimed to determine the distribution pattern and area of cover of exotic plants C. odorata in rehabilitation zone at Donglo Block, Resort of Wonoasri MBNP. The sampling of $C$. odorata used the transect plot method systematically, which carried out in Donglo Block Resort of Wonoasri MBNP. Data analyzed using Morisita index. The map of distribution pattern of $C$. odorata was created using the Geographic Information System (GIS). Based on the results of the Morisita index, the value $(\mathrm{I} \delta)=12.39$, which means that $C$. odorata has a clumped distribution pattern. The distribution pattern of $C$. odorata can also be seen from the visualization of the spatial distribution map, which shows that the growth of $C$. odorata in plants or overlaps with each other, hence that it looks clustered. The coverage area of $C$. odorata in the study location was $596,5 \mathrm{~m}^{2}$ or $29.24 \%$ of the total area of the study $\left(20,400 \mathrm{~m}^{2}\right)$. Based on the results of the coverage area of $C$. odorata, it was indicated that this exotic species is not yet classified as an invasive species in the area
\end{abstract}

How to cite: Rizkiah, D.W., Siddiq, A.M., \& Sulistiyowati, H. (2021). Distribution Patterns of Exotic Plant Chromolaena odorata (L.) in Rehabilitation Zone at Donglo Block, Resort of Wonoasri, Meru Betiri National Park. Jurnal Riset Biologi dan Aplikasinya, 3(1):1-6. DOI: https://doi.org/10.26740/jrba.v3n1.p1-6.

\section{INTRODUCTION}

Exotic plants are plants that are introduced intentionally or unintentionally from their native habitat to a new habitat (Radiansyah et al., 2015). Exotic plant species with competitive characters develop faster than native plant species and can become invasive in the future (Syah \& Arbain, 2019). Exotic plant species at a higher rate than native plants, and becoming invasive if these plants dominate in their new habitats. This is because exotic plants can absorb more energy and solar energy, which results in a higher growth rate compared to native plant species. One of the exotic plants that is potentially invasive is Chromolaena odorata (Yuliana \& Lekitoo, 2018).

The type of $C$. odorata is known by the Indonesian people as kirinyuh which is an annual woody herbaceous plant (Oktary et al., 2015). This plant is a wild plant that grows well in places with sufficient light, especially in open areas, edges of plantations, grasslands, and forests. One of the areas where kirinyuh plants are found in the Meru 
Betiri National Park (MBNP), as explained by (Susilo, 2018) that kirinyuh is an exotic plant species found in many of these conservation areas. According to (Suryawan et al., 2015) that the National Park is a biological conservation area where exotic plants are not recommended which could threaten the conservation of native species.

Based on the results of the 2020 survey, $C$. odorata is one of the exotic plant species found in various areas of the MBNP rehabilitation zone, particularly in the Donglo Block, Resort of Wonoasri. The presence of $C$. odorata may absorb the restoration of the rehabilitation of land ecosystem. This is because C. odorata is allowed to develop in the rehabilitation zone and it can become invasive in the future (Susilo, 2018). Initial efforts to identify these exotic plants as potentially invasive could use plant distribution patterns.

The distribution pattern is the distribution of organisms in nature that forms an interaction with their environment. The distribution pattern that often occurs in nature is clumped. The distribution of clumped within a population depends on the abiotic and biotic factors in the environment (Odum, 1971). Based on this, it is necessary to research the distribution pattern and area of coverage of exotic C. odorata plants in the rehabilitation zone of the
Donglo Resort Wonoasri Block TNMB, as an effort to restore rehabilitation land.

\section{MATERIALS AND METHODS}

\section{Time and Location of Research}

The research was conducted from March to December 2020. Data was collected in Donglo Block, Wonoasri Resort, MBNP, Jember Regency, East Java (Figure 1). The sampling area determined was 2.04 hectares. Description of types and data analysis at the Ecology Laboratory, Department of Biology, Faculty of Mathematics and Natural Sciences, University of Jember.

\section{Data retrieval}

The initial activity was to verify left-over specimens from in Donglo Block Resort of Wonoasri MBNP using the flora of Java (Backer, 1963). The species verification uses fresh plant specimens which include the roots, stems, leaves and flowers. The method used in collecting of $C$. odorata plant data was the systematic plot transect method. This method is carried out by systematic exploration of the transect line within the study site, then followed by placing 415 plots of $2 \times 2$ meters with a distance of 2 meters between plots

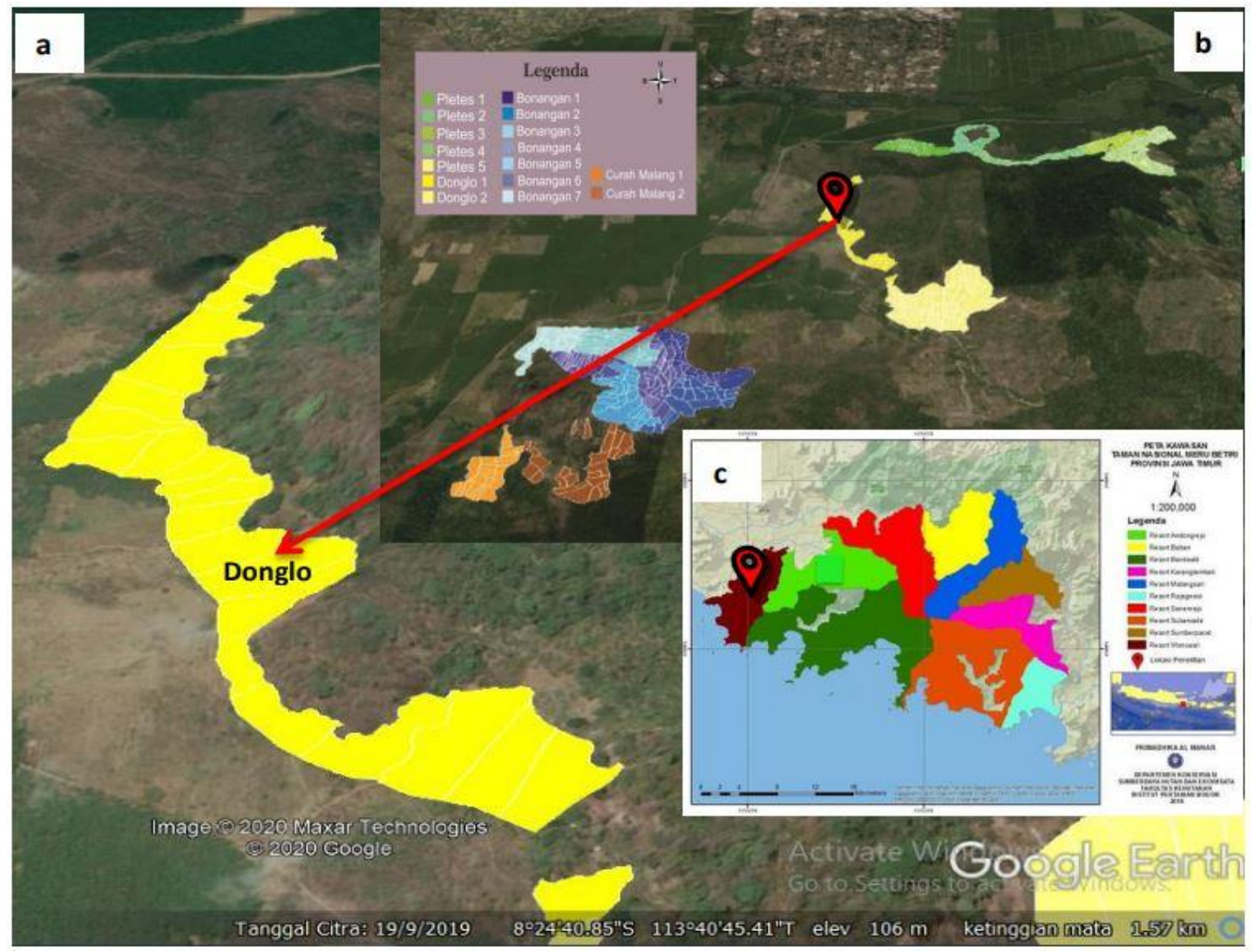

Figure 1. Map of research locations

(a.) Location of the Donglo Block; (b.) Location of the Wonoasri Resort; (c.) MBNP location 
and a distance of 5 meters between transects (Figure 2). The next step is coordinates mark using Garmin 64S GPS in the plot when finding $C$. odorata plants. The coordinate points of $C$. odorata plants by following the canopy pattern, namely forming coordinate points in the outermost areas of the plant. Measurement of the area of population control using the percent cover. This is used to determine what percentage of the plant occupies the research area. Abiotic factor data collection was also carried out which included air humidity, soil $\mathrm{pH}$, temperature, wind speed and light intensity. Abiotic factor data was collected in each representative sampling area.

\section{Data analysis}

The distribution pattern of $C$. odorata plants can be determined quantitatively by using the formula for the distribution index morisita (I $\delta$ ) (equation 1) according to Krebs (1989) as follows: $\mathrm{Id}=\mathrm{n}\left[\frac{\sum x^{2}-\sum x}{\left(\sum x\right)^{2}-\sum x}\right]$
Note:

$\mathrm{I} \delta=$ Morisita distribution index

$\mathrm{N}=$ Number of plots

$\sum \mathrm{x}=$ The percent of cover on each plot

$\sum \mathrm{x}^{2}=$ The total number of plots squared

The distribution pattern was determined using the following criteria

$\mathrm{I} \delta=1$, the distribution pattern tends to be random

I $\delta<1$, the distribution pattern tends to be even

I $\delta>1$, the distribution pattern tends to be clumped.

Mapping distribution data of exotic plants of $C$. odorata data using ArcGis 10.1 program. The data required the base map (Google Earth, 2020) and the coordinate point data for the distribution of $C$. odorata. The initial stage was to make rectification or registration of the base map on ArcMap. The next step is entering the coordinates (overlay) of $C$. odorata of the delineated results. Next step, the digitization and layering are done at

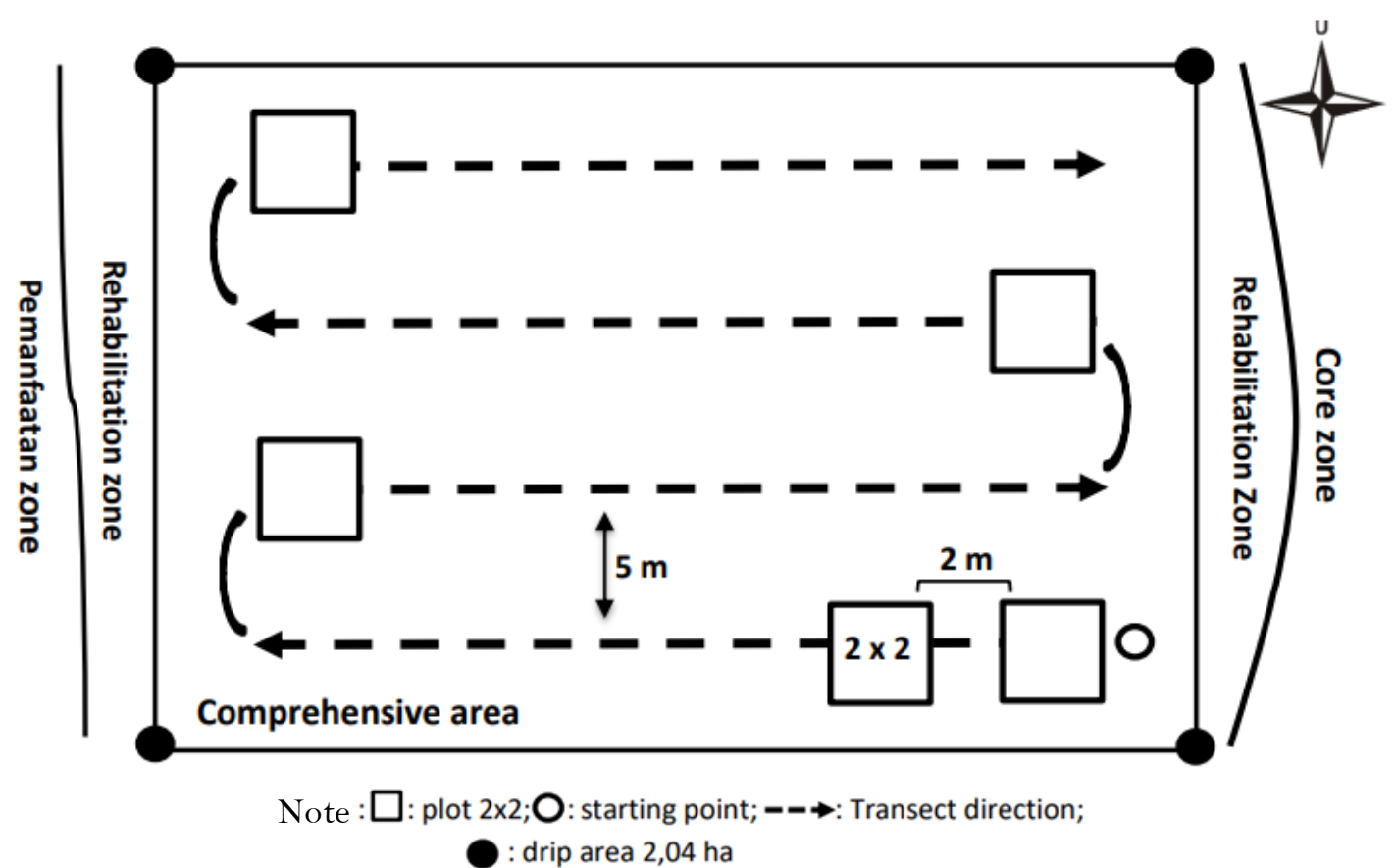

Figure 2. The systematic plot transect flow at the study site

each point of the coordinates of $C$. odorata which will then form a spatial distribution map. The final result of the determination using this GIS program is in the form of a spatial distribution map of $\mathrm{C}$. odorata in Donglo Block Resort of Wonoasri TNMB which is clumped (polygon) with a range of $2-5 \%$, and groups with a range of $6-10 \%$ and individuals who live solitary.
Determination of coverage area of exotic $C$. odorata plants in the study using the percent cover coverage. The percent cover data for each plot is converted to area data by dividing the percent cover obtained by the number of plots. The results obtained are multiplied by the total area of the study area then divided by the number of plots. Abiotic parameter measurements data were analyzed descriptively qualitatively to describe the 
environmental conditions where $C$. odorata was grown in the Rehabilitation Zone of the Wonoasri Resort, Meru Betiri National Park.

\section{RESULTS AND DISCUSSION}

\section{Distribution Patterns of Exotic Plants Chromolaena odorata}

Based on the results of the Morisita index analysis, the index value $(\mathrm{I} \delta)=12.39$, which means that the type of $C$. odorata in the Donglo Resort Wonoasri block MBNP has a clustered distribution pattern. The distribution pattern is said to be grouped by having a Morisita index value $>1$ (Krebs, 1989). The distribution pattern of C. odorata can also be seen from the results of the spatial distribution map (Figure 3). The map showed that C. odorata grows rapidly or overlaps with each other so that it appears clustered. Based on the map, $27 \%$ of the individuals living in solitary lives and groups of $73 \%$ of the total individuals found. It can be seen on the map that $C$. odorata clumped (polygons) with a range of $2-5 \%$, and clumped with a range of $6-10 \%$ and individuals who live solitary lives (waypoints).

Clumped distribution patterns occur when environmental conditions tend to be different and some individuals choose an environment that suits their life needs. This is inline with Susetiono (2004) stated that a population tends to clumped because it chosen an appropriate place to support its life. The pattern of clustered distribution is influenced by abiotic factors and biotic factors (Odum, 1993).
Abiotic factors at the research location, based on five environmental parameters including light intensity, air humidity, temperature, wind speed, and soil $\mathrm{pH}$. The following is the result of the total range of parameters for the measurement of abiotic environmental conditions carried out at ten sampling points, which can be seen in Table 1 .

The results of Table 1 showed that the abiotic parameters in the study location can still be tolerated by $C$. odorata. Light intensity at the study sites ranged from (146-959 Lux) which supported the growth of $C$. odorata. This is following Ambika (2006) showed that $C$. odorata can grow in the 504500 lux range. These plants grow in groups on land that is free of shade. The presence of shade will increase in leaf size to capture incoming light, so that the conditions of the shaded plants slowly expand the size of the leaves (Suci \& Heddy, 2018). The temperature and humidity parameters at the research location were between $32.1-39.8^{\circ} \mathrm{C}$ and the humidity ranged from $41.9-71.8 \% \mathrm{Rh}$. According to Tripathi et al. (2011) that temperatures above $20^{\circ} \mathrm{C}$ can increase the germination of $C$. odorata. Temperature and air environment are components of microclimate that greatly affect growth and pay attention to good environmental conditions for plants (Wijayanto \& Nurunnajah, 2012).

Soil $\mathrm{pH}$ parameters at the study sites were between 6.8-7 supporting the growth of $C$. odorata. This is consistent with the statement of Mandal \& Joshi (2014) that $C$. odorata can grow with various

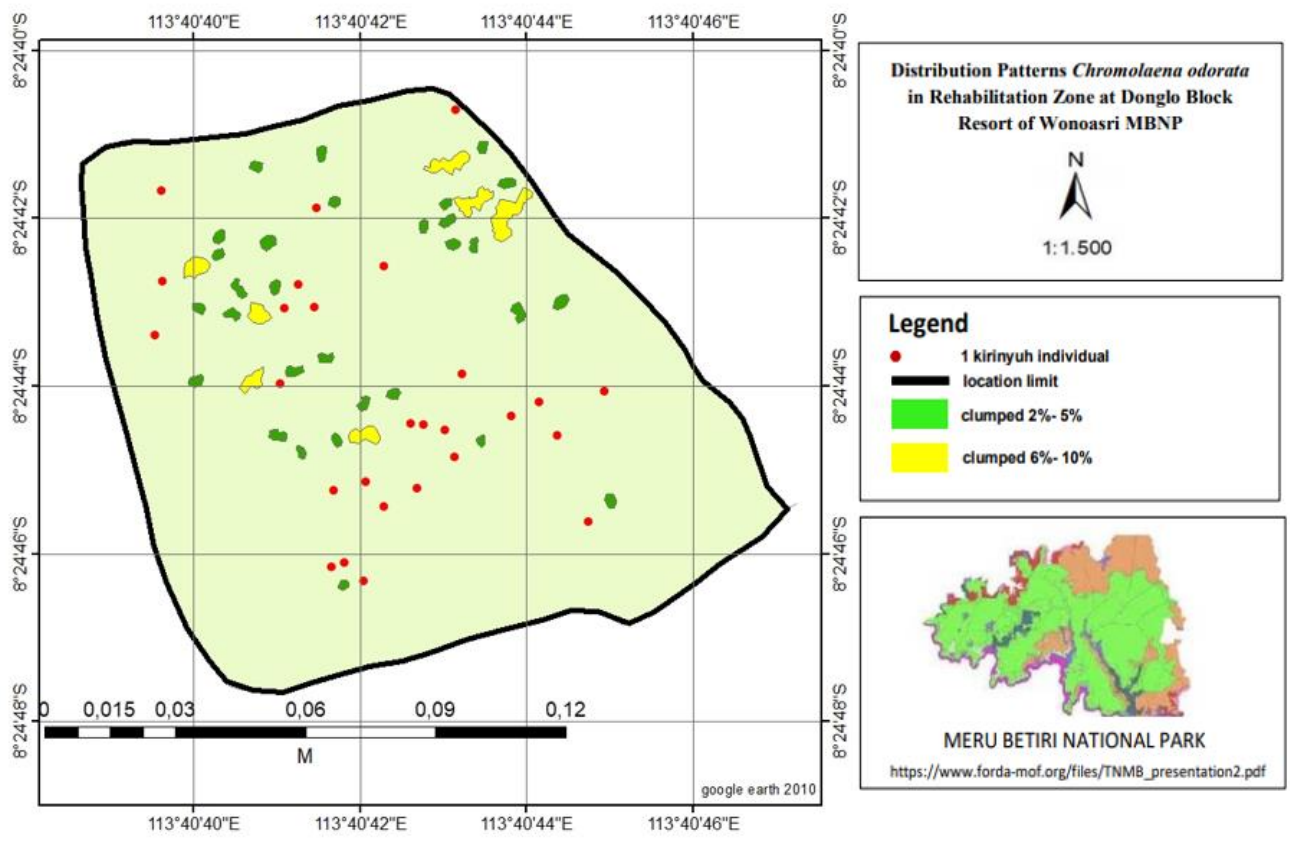

Figure 3. Map of the distribution pattern of $C$. odorata in the Rehabilitation Zone of the Donglo Resort Wonoasri Block MBNP 
Table 1. Abiotic measurement results

\begin{tabular}{lll}
\hline No & Abiotic parameters & Total \\
\hline 1 & Light intensity (lux) & $146-959$ \\
2 & Humidity $(\% \mathrm{Rh})$ & $41.9-71.8$ \\
3 & Temperature $\left({ }^{\circ} \mathrm{C}\right)$ & $32.1-39.8$ \\
4 & soil pH & $5.5-7$ \\
5 & wind velocity $(\mathrm{m} / \mathrm{s})$ & $0.1-2.4$ \\
\hline
\end{tabular}

soil conditions in the $\mathrm{pH}$ range 4-8. The wind speed parameter was $0.1-2.4 \mathrm{~m} / \mathrm{s}$, is sufficient to support the distribution of $C$. odorata seeds to the surrounding area. This is also seen in the numerous seeds of $C$. odorata, which are easily recognized by the wind due to the presence of needle-shaped hairs. According to Suharjo \& Aeny (2011) C. odorata is a plant that can continue to grow well in less fertile areas, and a strong wind that blows and there is no human intervention (empty land) will get a high $C$. odorata population.

Another factor that influences the distribution of this species is the reproductive phase. This plant reproduces by seeds or propagules that grow around its female. This is following the statement of Lestari et al (2017), which states that the distribution patterns of plants tend to be clustered because reproductive plants produce seeds that fall close to their parents. According to Prawiradiputra (2007), C. odorata can experience spread through cut stems, branches and the base of the stem which will sprout again, and the seeds that fall to the ground will germinate, so they can spread to form a shade.

\section{Coverage Area of $C$. Odorata Exotic Plants}

The coverage area of $C$. odorata in the study location was $596.5 \mathrm{~m}^{2}$ or $29.24 \%$ of the total area of the study $\left(20,400 \mathrm{~m}^{2}\right)$. According to Short and Coles (2001), the extent of the relationship is closely related to habitat and morphological form. Morphological factors that can affect the extent of coverage include roots, leaves, and seeds. The type of $C$. odorata has a taproot system that has many branches and a long cone shape, thus expanding the root area which can absorb water and nutrients. This plant also has characteristics on the surface of the wap leaves or what is commonly referred to as trichomes. Trichoma is a derivative from the epidermis which means hairs. The function of trichomes reduces the incidence of evaporation, temperature changes, and mechanical disturbances (Dewi et al., 2015). This is a form of protection from morphological adaptation so that these plants can survive growing and developing. Many C. odorata seeds in the presence of needle-shaped hair are commonly referred to as papus. Papus is persistent inside the fruit and opens outward like an umbrella that helps it float in the air (Silalahi, 2015), hence it can expand the distribution area because the seeds are easily known with the help of the wind.

The morphological characters of $C$. odorata are also influenced by the habitat. C. odorata species grow in clumped on land that is free from shade and based on the results of this area of cover, C. odorata is not yet included in the invasive species category in Donglo Block Resort of Wonoasri MBNP. This was possible due to competition with other introduced plants that were deliberately planted by rehabilitated land farmers, such as the presence of Pureria javanica. Therefore, the distribution of the exotic plants of $C$. odorata is not yet widespread in Donglo Resort Wonoasri MBNP.

\section{CONCLUSION}

The conclusion of this study is the distribution pattern of the exotic plants of $C$. odorata in Rehabilitation Zone at Donglo Block, Resort of Wonoasri MBNP is clumped. This is also supported by the map of the spatial distribution pattern of $C$. odorata which shows an overlap between close individuals with a grouping percentage of $73 \%$. Based on the results of the coverage area of $C$. odorata, it is indicated that this exotic species is not classified as an invasive species category in the area.

\section{ACKNOWLEDGMENT}

This research activity was carried out thanks to the support of the Tropical Natural Resources Conservation (T-NRC) of the University of Jember and the Conservation of Natural Resources of the Meru Betiri National Park.

\section{REFERENCES}

Ambika, S. (2006). Effect of light quality and intensity on emergence, growth and reproduction in Chromolaena odorata. Proceedings of the Seventh International Workshop on Biological Control and Management of Chromolaena Odorata and Mikania Micrantha, 2002, 1427. Available at http://jprsolutions.info.

Backer, C., and Reinier, C. B. V. B. 1963. Flora of Java. Universitas Michigan: P. Noordhoff.

Dewi, V. P., Hindun, I., \& Wahyuni, S. (2015). Studi Trikoma Daun Pada Famili Solanaceae Sebagai Sumber Belajar Biologi. JPBI (Jurnal Pendidikan 
Biologi Indonesia), 1(2), 209-218. https://doi.org/https://doi.org/10.22219/jpbi.v1i2.3 332.

Google Earth. 2020. https://earth.google.com/web/@8.38025995,113.69595945,30.16696257a,1 1499.39845 $315 \mathrm{~d}, 35 \mathrm{y}, \mathrm{oh}, 45 \mathrm{t}$,or/data=CksaSRJDCiUweDJkZDY 5 ZWYzOTFmOGY4YzU6MHgoZmFmNDBjMjNhO TM1NDJkGYUrwnCxCDAIQKPuXy 1a 1xAKghXb2 5vYXNyaRgCIAEoAg [accessed on 11 April 2020]

Krebs, C. J. 1989. Ecologycal Methodology. New York (ŨS): Harper and Row publisher.

Lestari, E.P., Dharmono, D., \& Amintari, S. (2017). Pola Distribusi Tumbuhan Mahar di Desa Batu Tangga Kecamatan Batang Alai Timur Kabupaten Hulu Sungai Tengah. Available at https://www.semanticscholar.org/paper/PolaDistribusi-Tumbuhan-Mahar-(Kleinhovia-hospitaLestari-

Dharmono/a260d961061 1bocb8bdaedb5da3ca6b8c14 6ebod.

Mandal, G., \& Joshi, S. P. (2014). Invasion establishment and habitat suitability of Chromolaena odorata (L.) King and Robinson over time and space in the western Himalayan forests of India. Journal of Asia-Pacific Biodiversity, 7(4), 391-400. https://doi.org/10.1016/j.japb.2014.09.002.

Oktary, A. P., Ridhwan, M., \& Armi. (2015). Ekstrak Daun Kirinyuh (Eupatorium odoratum) dan Lalat Buah (Drosophila melanogaster). Serambi Akademica, III(2), 335-342. https://doi.org/https://doi.org/10.32672/jsa.v7i2 .

Odum, E. P. 1993. Dasar-Dasar Ekologi. Edisi Ke-3. Yogjakarta: Gadjah Mada University Press.

Odum, E. P. 1971. Fundamental of Ecology Third Edition. London (GB): WB Saunders Company Press.

Prawiradiputra, B. (2007). Ki Rinyuh (Chromolaena Odorata (L) R.M. King Dan H. Robinson): Gulma Padang Rumput Yang Merugikan. 17(1), 46-52.

Radiansyah, D. A., Adi, S., Wandojo, S., Soekisman, T., Daisy, J. D., Titiek, S., Budi, S., Islana, E., Sugeng, H., Fauziah., Ridwan, A., Awliya, P. A., \& Nararya, G. 2015. Strategi Nasional dan Arahan Rencana Aksi Pengelolaan Jenis Asing Invasif di Indonesia. Jakarta: Deputi Bidang Pengendalian Kerusakan Lingkungan dan Perubahan Iklim, Kementrian Lingkungan Hidup dan Kehutanan Republik Indonesia.

Silalahi, M. 2015. Bahan Ajar Morfologi Tumbuhan. Jakarta: Universitas Kristen Indonesia
Short, F.T. and Coles, R. 2001. Global Seagrass Research Methods. The Netherlands: Elsevier Publishing.

Suci, C. W., \& Heddy, S. (2018). Pengaruh Intensitas Cahaya terhadap Keragaan Tanaman Puring (Codiaeum variegetum). Jurnal Produksi Tanaman, 6(1), 161-169. http://protan.studentjournal.ub.ac.id/index.php/prot an/article/view/627.

Suharjo, R., \& Aeny, T. N. (2011). Eksplorasi Potensi Gulma Siam ( Chromolaena Odorata). Jurnal Hama Dan Penyakit Tumbuhan Tropika, 11(2), 201-209. https://doi.org/https://doi.org/10.23960/j.hptt.21 12 01-209.

Suryawan, D., Sutyarto, E., Umaya, R., Kurnia, A \& Hadiyan, Y. (2015). Sebaran invasive alien species Acacia decurrens pada kawasan Taman Nasional Gunung Merapi. Pros Sem Nas Masy Biodiv Indon, $1(4)$, 738-742. https://doi.org/10.13057/psnmbi/mo 10409.

Susetiono. 2004. Fauna Padang Lamun tanjung Merah Selat Lembeh. Jakarta: Pusat Penelitian Oseanografi, LIPI.

Susilo, A. (2018). Inventarisasi Jenis Tumbuhan Asing Berpotensi Invasif di Taman Nasional Meru Betiri. Seminar Nasional Pendidikan Biologi dan Saintek, 3, 260-270.

Syah, T. \& Arbain. (2019). Assessment of Sesbania sesban as a Putative Invasive Species in Urban Area of Sangatta, East Kalimantan. Jurnal Ilmu Pertanian Indonesia, $24(4)$, 304-312. https://doi.org/10.18343/jipi.24.4.304

Tripathi, R. S., Yadav, A. S., \& Kushwaha, S. P. S. (2011). Biology of Chromolaena odorata, Ageratina adenophora and Ageratina riparia: A review. Invasive Alien Plants: An Ecological Appraisal for the Indian Subcontinent, August 2016, 43-56. https://doi.org/10.1079/9781845939076.0043.

Wijayanto, N. \& N. (2012). Intensitas Cahaya, Suhu, Kelembaban Dan Perakaran Lateral Mahoni (Swietenia Macrophylla King.) Di Rph Babakan Madang, Bkph Bogor, Kph Bogor. Jurnal Silvikultur Tropika, 3(1), 8-13.

Yuliana, S., \& Lekitoo, K. (2018). Deteksi Dan Identifikasi Jenis Tumbuhan Asing Invasif Di Taman Wisata Alam Gunung Meja Manokwari, Papua Barat. Faloak, 2(2), 89-102. https://doi.org/https://doi.org/10.20886/jpkf.2018.2 .2.89-102. 